\title{
HIGHLY ACTIVE CARBONS ON BASE OF BIOMASS WASTE - NUT SHELLS
}

\author{
Aleksandrs Volperts ${ }^{1}$, Lilija Jashina ${ }^{1}$, Dmitrijs Djachkovs ${ }^{1}$, \\ Botir Abduazimov $^{2}$, Galina Dobele ${ }^{1}$, Galina Telysheva ${ }^{1}$ \\ ${ }^{1}$ Latvian State Institute of Wood Chemistry, Latvia; \\ ${ }^{2}$ Institute of the Chemistry of Plant Substances, Uzbekistan \\ volperts@edi.lv
}

\begin{abstract}
The research is devoted to obtaining of highly porous activated carbons from apricot stones and pistachio, hazelnut, walnut shells from various regions using thermocatalytic activation with sodium hydroxide. Influence of the raw material properties and origin, as well as the precursor to activator ratio on a porous structure was studied. It was found that at activation temperature $700{ }^{\circ} \mathrm{C}$ and $\mathrm{NaOH}$ to carbonizate ration $2: 1$ and 3:1 a highly developed porous structure is being formed, which can be controlled altering meso- and micropores volumes. It is demonstrated that the highest porosity was achieved in the case of walnut shells and apricot stones, and the obtained materials can be used for sorption and as electrodes in supercapacitors, fuel cells and Li-ion batteries
\end{abstract}

Keywords: nut shells; activated carbons; porosity; pyrolysis

\section{Introduction}

Currently biomass attracts widespread attention worldwide. This can be explained, firstly, by the drive to find alternative renewable sources of organic precursors, as well as the interest towards phytotherapy.

Horticulture is an important food source and the main source of income in piedmont and mountain regions in many developing countries, including cultivation of nut and stone fruits for provisions and biologically active compounds.

It is known that kernels of many nuts, such as walnuts, pistachios and hazelnuts, are highly valuable food products, which have caloric values, nutritiousness and absorbency surpassing meats, bread, eggs, cow milk and other foods [1]. When nut kernels are processed for oils, wastes, comprising shells, amount to $40-55 \%$ from the nut weight. The main way of utilization of these wastes is burning them as fuel in furnaces alongside with other carbon-containing materials (Figure 1).

At the same time nut shells, as well as fruit stones, such as apricot, peach or cherry, have specific chemical-physical properties and can be used as highly valuable lignocellulosic precursors for production of carbonaceous sorbents [2-4]. Rational approaches to the processing of low-cost wastes improve the production feasibility and solve the utilization problems.

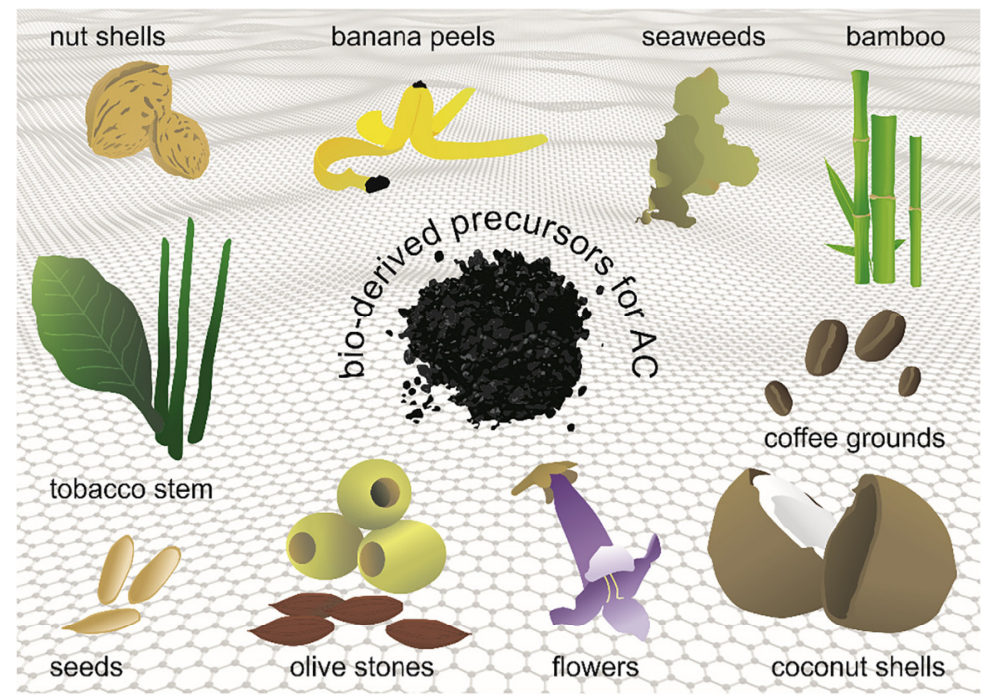

Fig. 1. Biomass-derived activated carbon precursors [5]

The main ways of carbonaceous sorbent application are within the framework of technological processes adsorption based purification, separation, extraction and concentration in gas and liquid media. The role of carbon sorbents constantly increases in the ecological problem solving, such as 
drinking water and sewage purification, industrial exhaust gas sorption in energetics. Other areas of carbonaceous sorbent application are medicine and pharmaceutics as hemosorbents and enterosorbents. Lately carbonaceous nanomaterials are being applied as electrodes in supercapacitors and as oxygen reduction catalysts in fuel cells [6-8].

Properties of carbonaceous materials mostly depend on the chemical properties of activators, since activation processes define various pathways of precursor transformation, which leads to formation of materials with different structures and properties. Alkali, such as $\mathrm{KOH}$ or $\mathrm{NaOH}$, are among the most effective activation agents, and allow obtaining of microporous sorbents with the specific surface more than $2000 \mathrm{~m}^{2} \cdot \mathrm{g}^{-1}$. These materials are currently widely studied, since control of the pyrolysis condition can lead to formation of activated carbons with the needed properties of nanoporous structures [9-11]. Alkali hydroxides interaction with the precursors takes place already at room temperature [12].

Thermally initiated reactions of the precursor with $\mathrm{MeOH}$ (where $\mathrm{Me}=\mathrm{K}^{+}$or $\mathrm{Na}^{+}$) are responsible for the three main processes:

1. formation of metal containing surface complexes,

2. their conversion into carbonates and oxides (mainly $\mathrm{Me}_{2} \mathrm{CO}_{3}$ and $\mathrm{Me}_{2} \mathrm{O}$ ) in reactions with the edge $\mathrm{C}$ atoms of the graphene plains,

3. $\mathrm{Me}_{2} \mathrm{CO}_{3}$ and $\mathrm{Me}_{2} \mathrm{O}$ reduction into metals.

Metal oxide reduction and bonding with carbon are two main factors, which provide formation and development of the porous structure [9]. If the process takes place in the optimal conditions (activator $\mathrm{KOH}$ or $\mathrm{NaOH}, 700-900{ }^{\circ} \mathrm{C}, 1-3$ hours), then the type of material (biomass, coal, etc.) does not influence the process anymore. The development of the porous structure directly depends on the presence of oxygen in the surface functional groups of the precursor [13]. It should be noted, that porosity of activated carbons is highly dependent on the ratio $\mathrm{MeOH} /$ precursor and the type of hydroxide. Without the alkali addition, it is practically impossible to obtain highly porous carbonaceous sorbents with developed nanoporosity [12; 14].

\section{Experiment}

Materials: pistachio shells (Pistacia) (Uzbekistan - Puz, USA - Pus); hazelnut shells (Corylus avellana) (Latvia - Cor); walnut shells (Júglans régia) (Uzbekistan - Jug); apricot stones (Prunus armeniaca) (Uzbekistan - Pr). The elemental composition and ash content of the samples is shown in Table 1.

Table 1

\section{Elemental analysis of the samples under study}

\begin{tabular}{|c|c|c|c|c|c|}
\hline Samples & $\mathbf{N}, \boldsymbol{\%}$ & $\mathbf{C ,} \%$ & $\mathbf{H}, \boldsymbol{\%}$ & $\mathbf{O}, \boldsymbol{\%}$ & Ash content, \% \\
\hline Puz & 0.46 & 49.66 & 4.45 & 45.42 & 0.31 \\
\hline Pus & 0.21 & 47.59 & 4.61 & 47.58 & 0.71 \\
\hline Cor & 0.28 & 51.05 & 4.51 & 44.16 & 0.99 \\
\hline Pr & 0.18 & 50.44 & 4.46 & 44.92 & 0.24 \\
\hline Jug & 0.23 & 50.90 & 4.74 & 44.14 & 0.81 \\
\hline
\end{tabular}

Carbonization was performed in a Nabertherm 401 muffle oven, Lilenthal, Germany. Heating rate $10^{\circ} \mathrm{C} \min ^{-1}$ up to $500{ }^{\circ} \mathrm{C}$, duration at max temperature $2 \mathrm{~h}$. Carbonizates were refined using a planetary mill Fritsch Pulverizette Classic 4. For the activation fraction $10 \mu \mathrm{m}$ were used.

Activation is schematically illustrated in Fig. 2 - it comprises two stages of thermal treatment. Carbonized material was impregnated with $50 \%$ water solution of $\mathrm{NaOH}$ in mass ratios of dry alkali to carbonizate $2: 1$ and $3: 1$. The mixture was activated at $700{ }^{\circ} \mathrm{C}$ for $120 \mathrm{~min}$. The pyrolysis product was washed with deionized water, hydrochloric acid and water again to achieve the filtrate $\mathrm{pH} 5$. Activated carbons were dried at $105^{\circ} \mathrm{C}$ overnight. The ash content in the samples was 0.1-0.5\%.

The porous structure of the $\mathrm{AC}$ was evaluated from $\mathrm{N}_{2}$ sorption/desorption isotherms determined in a sorptometer Quntachrome NOVA 4200e (Boynton Beach, FL, USA). Degassing was performed at $300{ }^{\circ} \mathrm{C}$ for $2 \mathrm{~h}$. The results were assessed using Quantachrome software and are based on the theories 
by Brunauer-Emmet-Teller (BET, in p/p0 range 0.05-0.35), Dubinin-Radushkevich (DR, in p/p0 range $10^{-5}-0.35$ ), and the density functional theory (DFT, in whole $\mathrm{p} / \mathrm{p} 0$ range).

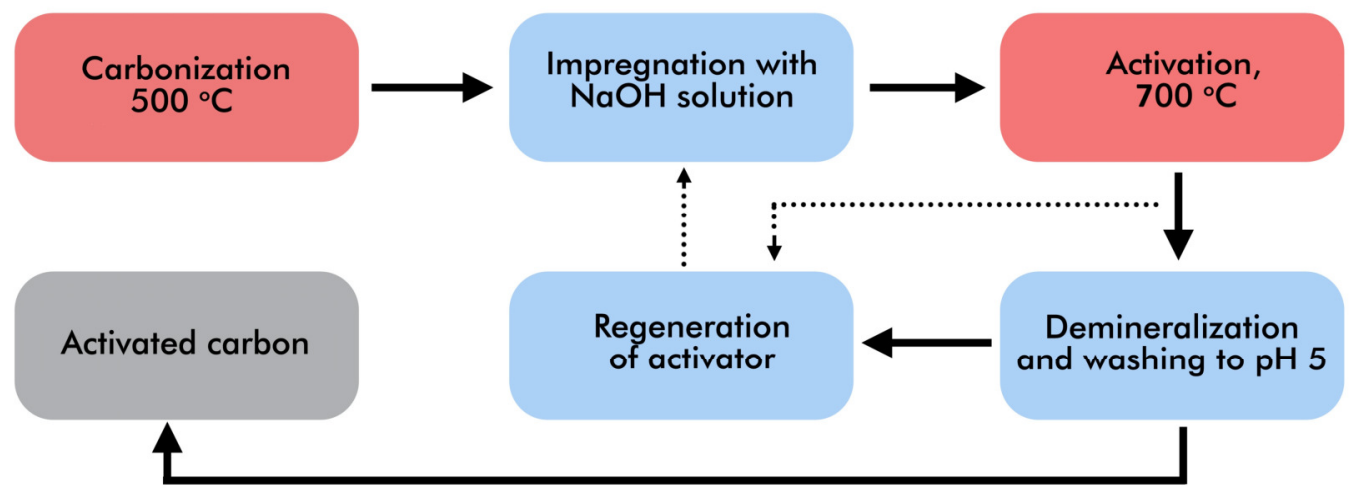

Fig. 2. Schematic representation of microporous carbon material synthesis

All experiments were made at least in quadruples and the experimental error was within $5 \%$.

\section{Results and discussion}

According to the elemental analysis (Table 1) the nut shells and apricot stones under study have a similar composition. The highest content of carbon, above $50 \%$, alongside with the lowest content of oxygen, was observed in the case of hazelnut and walnut shells, as well as apricot stones.

To obtain activated carbons on the base of various nut shells and apricot stones, precursors were carbonized and then refined. According to the thermal analysis data, the main part of organics of all samples under study is being removed in the temperature range $400-500{ }^{\circ} \mathrm{C}$ [15], thus the carbonization temperature was $500{ }^{\circ} \mathrm{C}$. Carbonizate yields altered negligibly in the range from 28.6 to $31.4 \%$ despite the different origin of precursors (Table 2). At the first stage of thermal treatment, namely carbonization, the framework of future active is being formed - the initial porosity.

Then the carbonizates were impregnated with the water solution of $\mathrm{NaOH}$ and subjected to thermochemical activation at $700{ }^{\circ} \mathrm{C}$ for $2 \mathrm{~h}$. The ratios of dry activator matter to carbonizate were 2 and 3 to 1 . At the second stage, the main reaction is the following $[12 ; 16]$ :

$$
6 \mathrm{NaOH}+2 \mathrm{C}=2 \mathrm{Na}+3 \mathrm{H}_{2}+2 \mathrm{Na}_{2} \mathrm{CO}_{3}
$$

The yield of activated carbons from the carbonizate at the ratio of activator to raw material 2:1 was more than $40 \%$, and when the ratio was 3:1, the yield decreased for 5-8\% (Table 2). According to the results of nitrogen sorption, it was found that all the obtained activated carbon samples have a highly developed porous structure, which is characteristic to the highly active sorbents (Figure 3). Judging from the isotherm slopes, all of the samples are microporous.

At the activator to carbonizate ratio 2:1, maximum specific surface parameters $\left(S_{B E T}\right)$ were observed in the case of walnut shells (Jug) and apricot stones (Pr) - more than $2200 \mathrm{~m}^{2} \cdot \mathrm{g}^{-1}$ (Table 2). The samples of active carbons based on hazelnut (Cor) and Uzbekistan pistachio (Puz) shells had a lower specific surface (above $1800 \mathrm{~m}^{2} \cdot \mathrm{g}^{-1}$ ).

Table 2

Ash content of samples and yield of carbonizates and activated carbons

\begin{tabular}{|c|c|c|c|c|c|}
\hline \multirow{3}{*}{ Samples } & \multirow{3}{*}{$\begin{array}{l}\text { Carbonizate } \\
\text { yield, } \%\end{array}$} & \multicolumn{2}{|c|}{$\begin{array}{l}\text { Yield of activated carbon } \\
\text { from the carbonizate, \% }\end{array}$} & \multicolumn{2}{|c|}{ Specific surface, $\mathrm{m}^{2} \cdot \mathrm{g}^{-1}$} \\
\hline & & \multicolumn{4}{|c|}{$\mathrm{NaOH}$ to carbonizate } \\
\hline & & $2: 1$ & $3: 1$ & $2: 1$ & $3: 1$ \\
\hline Puz & 28.6 & 43.0 & 38.8 & 1876 & 2395 \\
\hline Pus & 30.6 & 41.0 & 35.6 & 2148 & 2773 \\
\hline Cor & 30.7 & 44.0 & 35.8 & 1816 & 2171 \\
\hline $\operatorname{Pr}$ & 31.4 & 41.3 & 34.1 & 2223 & 2977 \\
\hline Jug & 29.9 & 42.0 & 36.0 & 2230 & 2982 \\
\hline
\end{tabular}



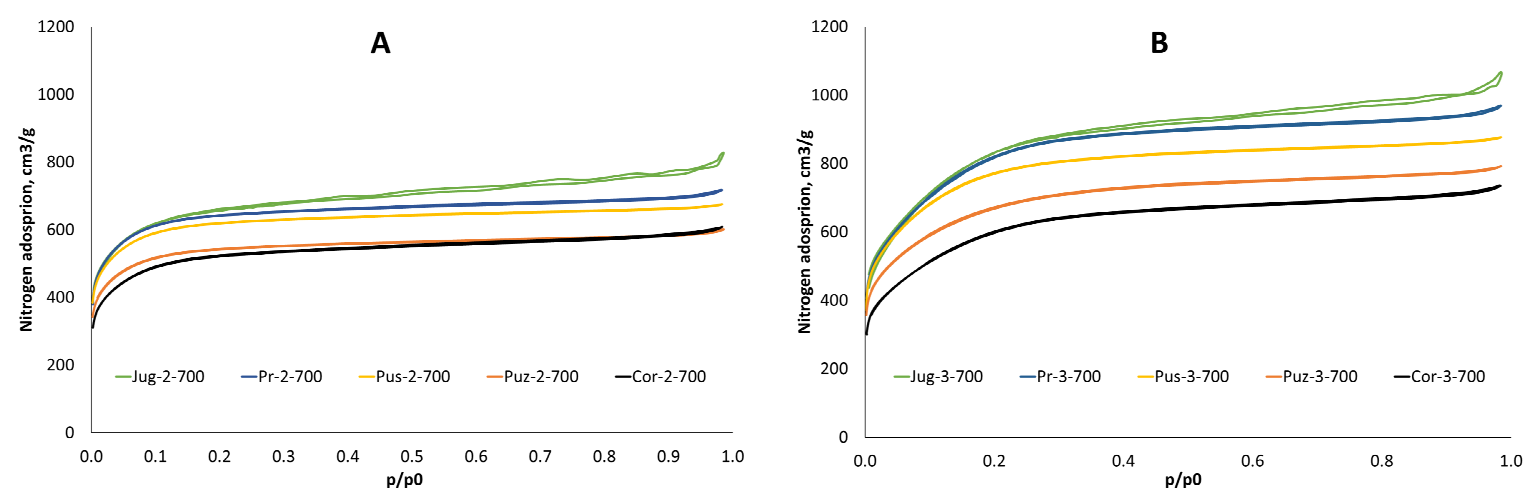

Fig. 3. Isotherms of nitrogen sorption and desorption at $77 \mathrm{~K}$ by the activated carbons on the base of nut shells and apricot stones: $\mathrm{A}-2: 1 \mathrm{NaOH}$ to carbonizate ratio; $\mathrm{B}-3: 1 \mathrm{NaOH}$ to carbonizate ratio

Porosity of the samples increases with the increase of the activator to carbonizate ratio from 2 to 3:1 (Figure 3). Not only the BET specific surface increases, which in case of Jug and Pr surpasses the theoretical possible and is more than $2900 \mathrm{~m}^{2} \cdot \mathrm{g}^{-1}$, but also the average pore size and the total pore volume, which reaches values more than $1.5 \mathrm{~m}^{3} \cdot \mathrm{g}^{-1}$ (Figures 3, 4, 5).
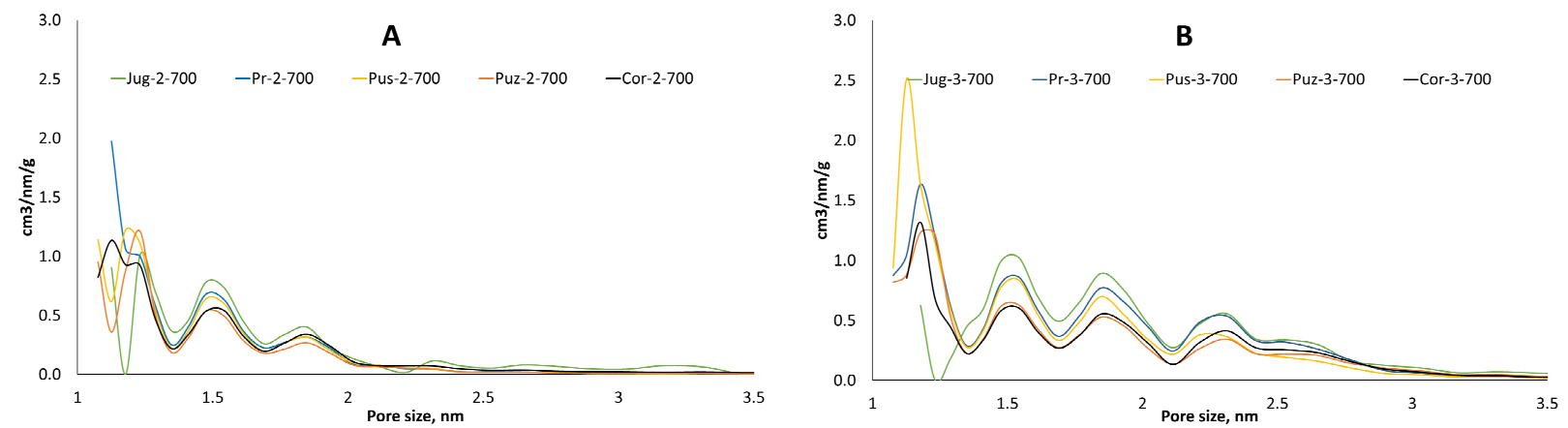

Fig. 4. Pore size distribution of the activated carbons on the base of nut shells and apricot stones: A $-2: 1 \mathrm{NaOH}$ to carbonizate ratio; $\mathrm{B}-3: 1 \mathrm{NaOH}$ to carbonizate ratio

With the increase of the activator ratio also the volume of mesopores with sizes 2-3 nm increases (Figures 3 and 4). The alteration of the porous structure is also supported by the presence of hysteresis on the isotherms, which points at capillary condensation phenomena in the process of nitrogen sorption. This can enhance the area of application of these sorbents, particularly in sorption of liquids.
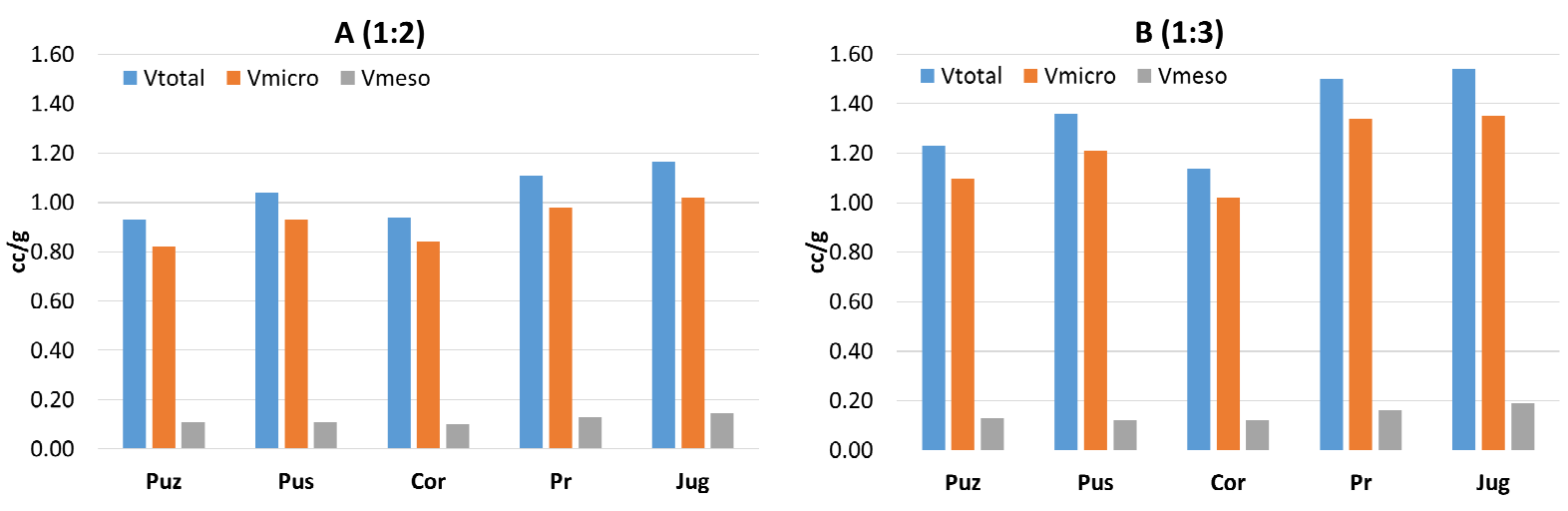

Fig. 5. Total volume and ratio of micro- and mesopores of the activated carbons on the base of nut shells and apricot stones: $\mathrm{A}-2: 1 \mathrm{NaOH}$ to carbonizate ratio; $\mathrm{B}-3: 1 \mathrm{NaOH}$ to carbonizate ratio

The obtained nanoporous sorbents on the base of nut shells and apricot stones, as well as other types of plant biomass, can be widely applied not only for sorption, but also for energy accumulation and transfer - as electrodes in supercapacitors, fuel cells and Li-ion batteries [6; 17]. 


\section{Conclusions}

Highly active nanoporous carbons on the base of carbonizates of nut shells and apricot stones were obtained using alkali thermochemical activation with $\mathrm{NaOH}$. It was found that at the activation temperature $700{ }^{\circ} \mathrm{C}$ and $\mathrm{NaOH}$ to carbonizate ration $2: 1$ and 3:1, a highly developed porous structure is being formed, which can be controlled altering meso- and micropores volumes. It is demonstrated that the highest porosity was achieved in the case of walnut shells and apricot stones, with the BET specific surface surpassing the theoretical possible, more than $2900 \mathrm{~m}^{2} \cdot \mathrm{g}^{-1}$, and the total pore volume more than $1.5 \mathrm{~m}^{3} \cdot \mathrm{g}^{-1}$. The incredibly high porosity of the obtained activated carbons blazes the avenue for the widest spectrum of their applications.

\section{Acknowledgements}

The study was supported by LZP-2018/1-0194 project "Nanostructured Nitrogenated Carbon Materials as Promoters in Energy Harvesting and Storage Technologies (NN-CARMA)", Bioeconomic grant "BioCat" from the Latvian State Institute of Wood Chemistry, and scientific collaboration No.20-19 between LSIWC and ICPS ASc RUz (agreement No. 135 PD-19-UzLat) with grant support "El-yurt umidi" foundation, Agency for the Development of Public Service under the President of the Republic of Uzbekistan.

\section{References}

[1] Toktorbaeva G., Tashpolotov Y. Pyrolysis Processes of the Shell of the Juglans regia L. in the Temperature Range of $250-550^{\circ} \mathrm{C}$ to Produce Charcoal. Bull Sci Pract, vol. 5, 2019, pp. 135-140.

[2] Queirós C.S.G.P., Cardoso S., Lourenço A., et al. Characterization of walnut, almond, and pine nut shells regarding chemical composition and extract composition. Biomass Convers Biorefinery, vol. 10, 2020, pp. 175-188.

[3] Kambarova G.B., Sarymsakov S. Preparation of activated charcoal from walnut shells. Solid Fuel Chem, vol. 42, 2008, pp. 183-186.

[4] Farberova E.A., Tingaeva E.A., Chuchalina A.D., et al. Obtaining granulated active carbon from wastes of vegetable raw materials. Izv Vyss Uchebnykh Zaved Seriya Khimiya i Khimicheskaya Tekhnologiya, vol. 61, 2018, pp. 51-57.

[5] Fic K., Platek A., Piwek J., et al. Sustainable materials for electrochemical capacitors. Mater Today, vol. 21, 2018, pp. 437-454.

[6] Volperts A., Plavniece A., Dobele G., et al. Biomass based activated carbons for fuel cells. Renew Energy, vol. 141, 2019, pp. 40-45.

[7] Dobele G., Volperts A., Telysheva G., et al. Wood-based activated carbons for supercapacitors with organic electrolyte. Holzforschung, vol. 69, 2015, pp. 777-784.

[8] Chernyavina V. V., Berezhnaya A.G., Zhikhareva E.A. Activated Carbon "NORIT B Test EUR" as an Electrode Material for Supercapacitors. Electrochem Energ, vol. 18, 2018, pp. 192-198.

[9] Eletskii P.M., Yakovlev V.A., Parmon V.N. Modern approaches to the production of carbon materials from vegetable biomass. Theor Exp Chem, vol. 47, 2011, pp. 139-154.

[10] Torné-Fernández V., Mateo-Sanz J.M., Montané D., et al. Statistical Optimization of the Synthesis of Highly Microporous Carbons by Chemical Activation of Kraft Lignin with $\mathrm{NaOH}$. J Chem Eng Data, vol. 54, 2009, pp. 2216-2221.

[11]Dobele G., Dizhbite T., Gil M.V. V., et al. Production of nanoporous carbons from wood processing wastes and their use in supercapacitors and $\mathrm{CO} 2$ capture. Biomass and Bioenergy, vol. 46, 2012, pp. 145-154.

[12] Tamarkina Y.V., Kucherenko V.A., Shendrik T.G., et al. Preparation of nanoporous adsorbents from brown coal using alkali activation and thermal shock. Хімія, Фізика Та Технологія Поверхні, vol. 3, 2012, pp. 133-141.

[13] Béguin F., Elzbieta F. Carbons for electrochemical energy storage and conversion systems. Boca Raton: CRC Press, 2010

[14] Sych N.V., Trofymenko S.I., Poddubnaya O.I., et al. Porous structure and surface chemistry of phosphoric acid activated carbon from corncob. Appl Surf Sci, vol. 261, 2012, pp. 75-82. 
[15] Temirkhanov B.A., H. S., Archakova R.D., et al. Синтез высокоэффективных сорбентов из скорлупы грецкого ореха. Сорбционные и хроматографические процессы, vol. 12, 2019, pp. 1025-1032. (In Russian).

[16] Hameed B.H., El-Khaiary M.I. Equilibrium, kinetics and mechanism of malachite green adsorption on activated carbon prepared from bamboo by $\mathrm{K} 2 \mathrm{CO} 3$ activation and subsequent gasification with CO2. J Hazard Mater, vol. 157, 2008, pp. 344-351.

[17] Volperts A., Dobele G., Zhurinsh A., et al. Wood-based activated carbons for supercapacitor electrodes with a sulfuric acid electrolyte. Xinxing Tan Cailiao/New Carbon Mater, vol. 32, 2017 , pp. 319-326. 